\title{
Mid Ordovician commensal relationships between articulate brachiopods and a trepostome bryozoan from eastern Canada
}

\author{
Dave A.T. Harper ${ }^{1}$ and Ron K. Pickerill ${ }^{2}$ \\ 1 Department of Geology, University College, Galway, Ireland \\ 2Department of Geology, University of New Brunswick, Fredericton, New Brunswick E3B 5A3, Canada
}

Date Received September 15, 1995

Date Accepted February 14, 1996

\begin{abstract}
A mid Ordovician microcommunity of sessile filter feeders, from the Trenton Group of eastern Canada, developed as a commensal relationship between an arborescent trepostome bryozoan and two taxa of articulate brachiopod. An unusual specimen preserves a life assemblage of over 30 individuals of Onniella and provides an explanation for some occurrences of Lower Palaeozoic pedunculate brachiopods in dark shales.

Une microbiocénose de l'Ordovicien moyen de filtreurs sessiles du groupe de Trenton dans l'Est du Canada, s'est développée par le biais d'une relation commensale entre un bryozoaire trépostome arborescent et deux taxons de brachiopodes articulés. Un spécimen particulier préserve une communauté de plus de 30 sujets d'onnielles et permet d'expliquer la présence de certains brachiopodes pédonculés du Paléozoĭque inférieur dans des schistes foncés.
\end{abstract}

[Traduit par la rédaction]

\section{INTRODUCTION}

The occurrence of pedunculate brachiopods in fine grained sedimentary strata has persistently presented a dilemma to palaeoecologists. A variety of life modes has been presented in explanation. Large terebratulides such as living Gyrothyris, Neothyris and Terebratella (Richardson, 1981a,b) and probably the fossil Tichosina (Harper et al., 1995), from the Pleistocene of Jamaica, atrophied their pedicles and pursued a recumbent life strategy resting within the mud. Muir-Wood (1959), however, illustrated the terebratulide Chlidonophora attached by a brush-like pedicle to the Globigerina Ooze of the Indian Ocean, whereas the thread-like pedicle of deepsea Cryptopora anchored the minute rhynchonellide within a soft substrate and permitted the animal to rise above periodic, dilute turbidity currents (Curry, 1983). Ager (1962) suggested that some small, thin-shelled rhynchonellides found in mudstones, such as the Devonian Leiorhynchus, may have been epiplanktonic, attached to floating seaweed whereas, Gwynia, the smallest known articulate brachiopod, probably occupied a niche within the interstitial fauna of the substrate (Harper et al., 1996).

We present here evidence of an Ordovician commensal arrangement between an arborescent trepostome bryozoan and a population of the dalmanellid Onniella. The articulate brachiopods were associated with the bryozoan by pedunculate attachment and the assemblage provides evidence of a specialized, benthic, epifaunal life strategy for this type of brachiopod commonly found unattached in fine grained, deep-water sediments. Attachment to the bryozoan colony provided anchorage, support and a preferential feeding position far removed from the sediment-water interface. These small brachiopods formed a secondary epifaunal tier of sus- pension feeders above a soft sediment substrate (Bottjer and Ausich, 1986). Moreover, such tiers were firmly established by the Mid Ordovician.

\section{LOCATION, STRATIGRAPHY \\ AND GEOLOGICAL SETTING}

Material described herein was collected from a small working quarry at Château Richer, approximately $22 \mathrm{~km}$ northeast of Quebec City, Quebec, eastern Canada (Fig. 1). This quarry is situated in Middle Ordovician (Orthograptus ruedemanni Biozone) limestones of the Trenton Group, the youngest carbonate unit in the Taconic foreland basin of southern Quebec (Lavoie, 1995). It represents one of the more northeasterly locations of this lithostratigraphic unit that is more extensively exposed to the southwest in the St. Lawrence Lowlands and then onward into the U.S.A.

In Quebec the Trenton Group has been interpreted as a transgressive continental (Laurentian), platformal margin sequence deposited on a carbonate ramp that initially developed in warm-water tropical and later in temperate conditions (Lavoie, 1995). In the St. Lawrence Lowlands, the sequence is 140 to $220 \mathrm{~m}$ in thickness and is represented by an essentially tripartite, but nomenclaturally diverse, succession (for formational terminology see Harland and Pickerill, 1982; Lavoie, 1995). In Quebec City and northeastwards this is represented, from oldest to youngest, by the Pont Rouge, Deschambault and Neuville formations.

The quarry at Château Richer is located within the uppermost Neuville Formation (and in the youngest Grondines Member), where approximately $5 \mathrm{~m}$ of thinly interbedded, grey lime mudstones or siltstones and calcareous shales are exposed. There, this sequence has been interpreted as rela- 

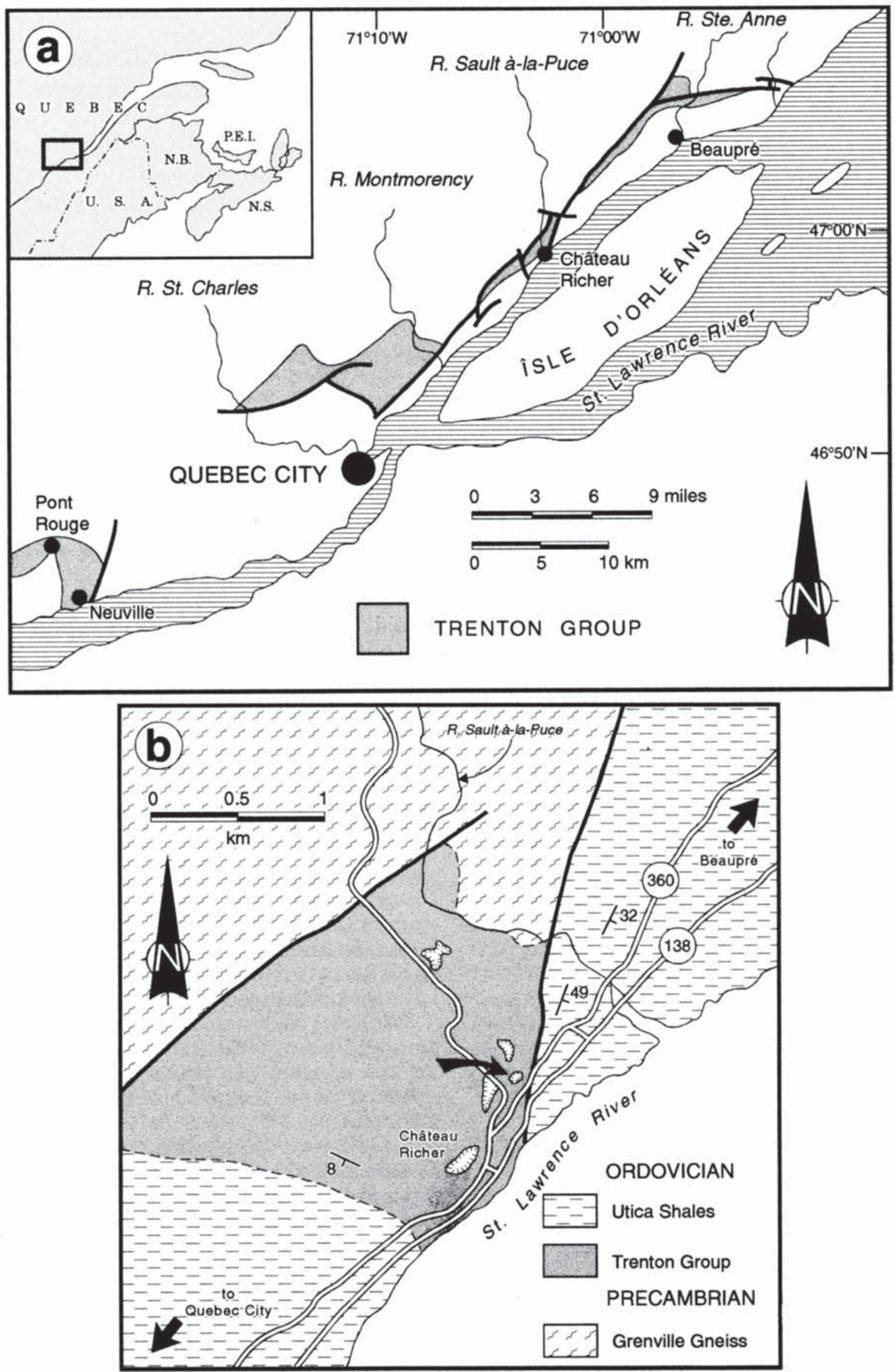

Fig. 1(a). Outcrop map of the Trenton Group adjacent to Quebec City; the locality at Château Richer is on the central part of the map, northeast of Quebec City. Inset shows geographical location of the area. (b). Detailed geological and location map of the area around Château Richer, the locality is indicated by a curved arrow. Solid black lines in (a) and (b) represent major faults. 
tively deep-water in origin, deposited in outer shelf conditions at or, even more likely, below storm-wave base (Harland and Pickerill, 1982), a conclusion also supported by trace fossil evidence (Pickerill and Forbes, 1979). This interpretation is also strengthened by the presence of abundant, parautochthonous, brachiopod-dominated assemblages, virtually complete and articulated examples of crinoids and, albeit rare, examples of annelids (Conway Morris et al., 1982). As further support, the Trenton Group is transitionally overlain by graptolitic strata of the Utica Shales, a black limey shale unit, with thin layers of lime mudstone and siliciclastic siltstone, that is interpreted as an oxygen-stratified basinal deposit (Lavoie, 1995, and references therein).

Limestones of the Trenton Group in the St. Lawrence Lowlands are famous for their richly fossiliferous nature and even preserve examples of linguloid brachiopod pedicles (Pickerill and Forbes, 1978), annelids (Pickerill and Forbes, 1978; Conway Morris et al., 1982) and appendages of several species of trilobite (Raymond, 1920; Størmer, 1939, 1951). However, with the exception of the short report by Harland and Pickerill (1987), commensal relationships such as the one described herein remain undocumented.

\section{COMMENSAL ARRANGEMENTS}

Two articulate brachiopod taxa were associated with the branches of the bryozoan (Fig. 2a). The bryozoan is preserved as mainly mouldic material; a more precise identification is not possible. The dalmanellid Onniella accounted for virtually all of the more than 30 brachiopod specimens on the block. The specimens are similar to Onniella multisecta (Meek); individuals are consistently small, although this may reflect immaturity, with a subcircular outline, relatively welldefined ventral and dorsal muscle scars together with delicate cardinalia. They occur in clusters sporadically developed along the branches of the bryozoan (Fig. 2b). About $20 \%$ of the specimens counted appear trapped behind branches of the bryozoan following the postmortem collapse of the colony; some also form small shell hashes under the colony, whereas others may have been dislodged or buried in the sediment after the colony was felled.

Approximately equal numbers of ventral and dorsal valves were counted on the block; all were disarticulated, but the majority were complete and well preserved. The sagittal lengths of 15 ventral and 15 dorsal valves were measured and analyzed; a selection of univariate graphics is presented on Figure 3 . The dorsal valves (mean 2.1 , variance 0.74 ) are significantly smaller than the ventral valves (mean 2.4 , variance $0.44)$. Both the ventral and dorsal valve distributions are positively skewed, suggesting the high infant mortality usually associated with life assemblages. Clearly the specimens of Onniella were attached in life, by fairly short, robust pedicles; most of the shells are preserved in direct contact with the branches of the bryozoan (Fig. 2a).

The second brachiopod morphotype is represented by a single internal mould of a subquadrate ventral valve with a strongly impressed costellate ornament, characterised by a prominent median rib (Fig. 2b). The valve is an immature rafinesquinid, slightly dissociated from both the branches of the bryozoan and the clusters of Onniella. Rafinesquinids probably possessed active pedicles during early growth stages; however, these were atrophied as adults pursued recumbent life styles within soft substrates. Ambitopic forms such as the rafinesquinids may have taken advantage of this type of substrate to establish the larval shell.

The Château Richer assemblage is immediately overlain by black mudstone, indicating the microcommunity was probably engulfed by a dilute surge of black anoxic mud, rapidly preserving the association, more or less, in situ.

\section{Discussion}

Articulate brachiopods are relatively rare in Lower Palaeozoic dark shales and siltstones. Traditionally their occurrence has been associated with plankton as epi-or pseudoplankton, living attached to floating organic material such as algae (Bulman, 1964) with a postmortem descent to the seabed prior to burial. Wignall and Simms (1990), in a review of Phanerozoic pseudoplankton, have suggested that the discinoid 'trematids' and the plectambonitoid 'aegiromenids' pursued adpressed pseudoplanktonic life strategies. Havliček (1967) favoured an epiplanktonic life mode for species of Chonetoidea and Sericoidea that are relatively common in the Ordovician and Silurian of Bohemia. Bergstrom (1968) reviewed a number of brachiopod assemblages from graptolitic shales dominated by obolids (middle Dicellograptus Shale, Bornholm), sowerbyellids (lower Dicellograptus Shale, Bornholm and the Sularp Shale, Scania) and chonetids (Bringewood Formation, Shropshire). Many of these brachiopods, despite simple deltidiodont dentition, were still articulated, suggesting very rapid post- or synmortem burial. Sheehan (1976), however, suggested that these and similar assemblages, preserved in mudstones and shales, may have been attached to biodegradable material, such as plants, rooted to the seafloor.

Nevertheless, a number of unequivocal in situ, deepwater, brachiopod-dominated faunas have been documented from fine grained siliciclastic facies. The late Ordovician Foliomena fauna (Harper, 1979; Cocks and Rong, 1988) is a sparse, dispersed biota dominated by thin-shelled, minute brachiopods drawn from the main Lower Palaeozoic orders; the dalmanelloid Dedzetina, the plectambonitoid Christiania, the strophomenoid Foliomena, and the athyroid Cyclospira are the key elements of this specialized fauna with a near global distribution. The palaeoenvironmental distribution of the fauna was probably related to areas of low oxygen levels with sparse nutrient supplies (Rong et al., 1994).

Jaanusson (1984) developed a model for offshore-onshore, articulate brachiopod distributions based on an analysis of Late Ordovician brachiopod-dominated assemblages from Europe and North America. On the outer shelf and upper slope, associations occur with the plectambonitoids Chonetoidea and Sericoidea together with lingulates. These associations are probably comparable to the Foliomena-type fauna and may have developed adjacent or upslope. In coarser, more nearshore sediments the Chonetoidea-Sericoidea-type fauna 

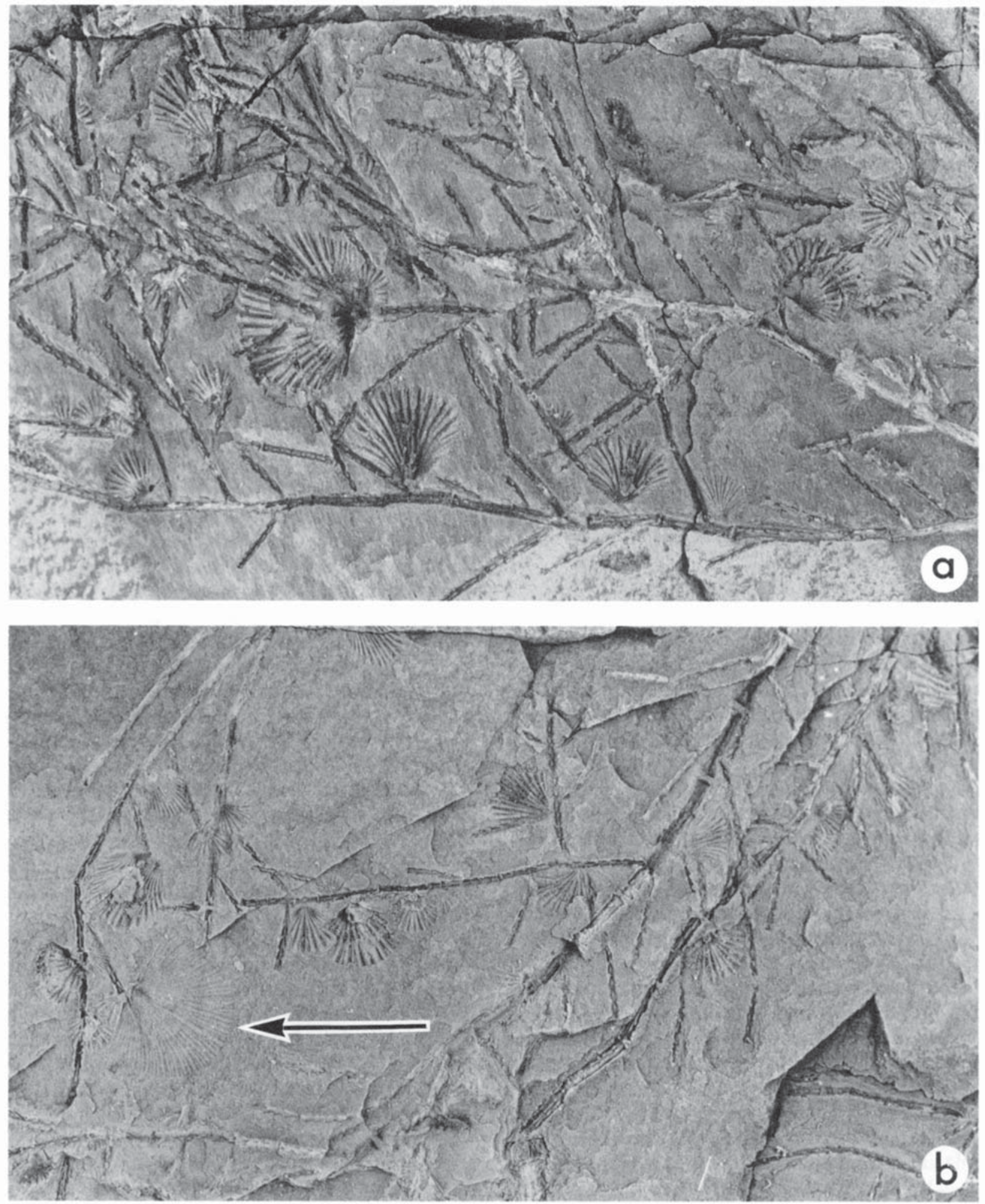

Fig. 2(a). Detail of clusters of Onniella attached to the bryozoan (block NBMG 9976 reposited in the New Brunswick Museum). (b). Free-living rafinesquinid brachiopod (bottom left, indicated by arrow) loosely associated on same block with the microcommunity of attached Onniella. Magnification of both x8.

is joined by the dalmanelloid Onniella. Generally, Onniella is smaller and less common in darker sediments whereas small individuals of Chonetoidea and Sericoidea, together with micromorphic acrotretoids such as Hisingerella, are relatively abundant. For example, transitions from assem- blages dominated by Hisingerella and Sericoidea to those with Onniella and Sericoidea were demonstrated through an upward-coarsening sequence during the late Caradoc in the Oslo basin (Harper et al., 1985). More anoxic conditions may have favoured nonarticulates and small plano- to 

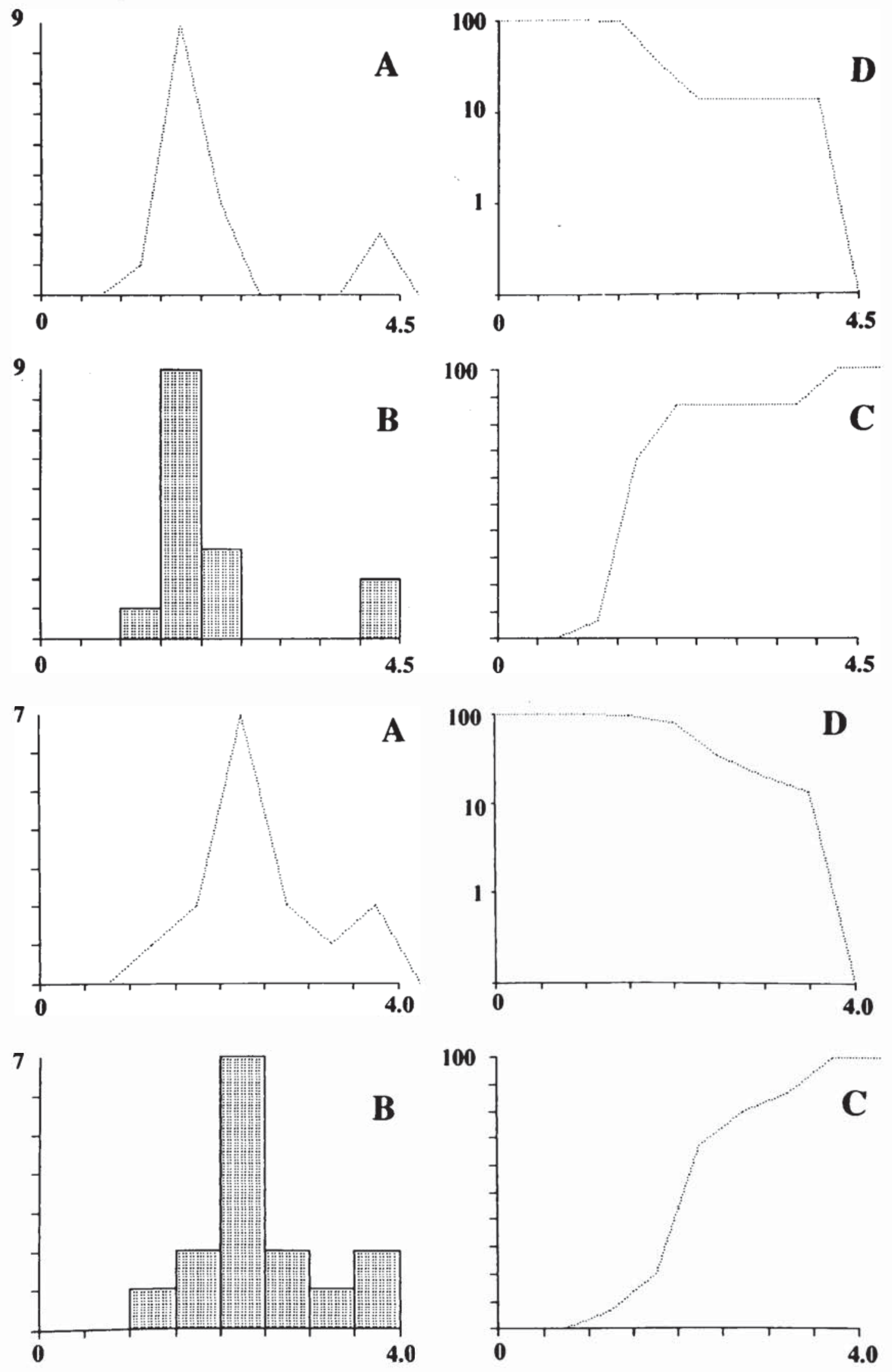

Fig. 3. Univariate graphs of the sagittal lengths of the dorsal (upper) and ventral (lower) valves - (A) Size frequency polygon, (B) Size frequency histogram, (C) Cumulative frequency polygon, (D) Survivorship curve. X axes of all four graphs scaled in $\mathrm{mm}$; $\mathrm{Y}$ axes of (A) and (B) represent number of specimens, (C) and (D) as \% of total number of specimens. 
concavoconvex plectambonitoids. Although the plectambonitoids may have pursued a recumbent strategy, partly within the fine grained substrate (Jaanusson, 1984) and the acrotretoids were possibly part of the interstitial fauna (Bassett, 1984), the life mode of the larger pedunculate articulates, associated with relatively fine sediment, remains an enigma.

Attachment of brachiopods to other organisms is not unusual but direct evidence of attachment is not commonly preserved in the fossil record. The majority of examples reported, however, involve various strophomenides attached by spines to crinoids (Etheridge, 1876; Unklesbay and Niewoehner, 1959; Grant, 1963). Some pedunculate forms, such as the spiriferide Spiriferina from the Carboniferous of Scotland (Etheridge, 1876) and the rhynchonellide Microsphaeridiorhynchus nucula (J. de C. Sowerby) from the Silurian of Shropshire (Holland, 1971), were demonstrably attached to their hosts by pedicles. Schumann (1969) described attachment by byssus-like pedicles in the Devonian brachiopods Kiangsiella and Uncites. In addition, Grant (1963) has documented immature growth stages of the productoid Waagenoconcha, attached to crinoid stems prior to adult life as a recumbent living within the substrate stabilized by spines. Sandy (1996) has reported the attachment of the atrypoid Zygospira to a crinoid stem in the Waynesville Formation of Ohio, extending the record of peduculate attachment to crinoids back to the late Ordovician. Moreover, the attachment of a specimen of Paterina to the enigmatic Wiwaxia from the Middle Cambrian Burgess Shale and equivalent deposits (Conway Morris, 1985) suggests this type of attachment has a long history, probably covering the entire Phanerozoic.

Nevertheless, evidence of the attachment of orthide brachiopods is rare. Wright (1968) illustrated a remarkable suite of specimens of the dalmanelloid Dicoelosia; five shells were apparently attached, by their pedicles, to a linear organic fragment. The Trenton microcommunity described above, dominated by the pedunculate epifaunal Onniella, is a clear example of a commensal arrangement between articulate orthide brachiopods and a bryozoan colony. Onniella multisecta is common in the Reedsville Shale and equivalent strata of the northeastern parts of the central Appalachians (Bretsky, 1969). There, Onniella occurs with Sowerbyella associated with muddy or silty substrates usually in highly concentrated patches. Bretsky (1969, p. 84) suggested O. multisecta was directly attached to the substrate or to other shells and nonpreservable organics such as worm tubes or algae. The data presented herein firmly supports this interpretation. Lack of suitable taphonomic conditions probably accounts for the scarcity of such specimens displaying commensal relationships elsewhere in the fossil record. Rather, pedunculate brachiopods were detached from their hosts, soon after death, for burial in adjacent sediment.

\section{ACKNOWLEDGEMENTS}

D.A.T.H. thanks the National Geographic Society for finance to visit Canada and initiate this collaboration. Fi- nancial support was provided to R.K.P. by a Natural Science and Engineering Council of Canada operating grant which is gratefully acknowledged. We wish to thank A. Gómez, D. Campbell and L. MacDonald for technical assistance in all phases of the preparation of this manuscript and W.H. Forbes for donating the slab on which the study is based. S.K. Donovan furnished useful comments on the manuscript and Randy Miller provided a repository number (NBMG 9976) for the New Brunswick Museum. We thank M.R. Sandy and P.M. Sheehan for constructive and encouraging reviews.

Ager, D.V. 1962. The occurrence of pedunculate brachiopods in soft sediments. Geological Magazine, 99, pp. 184-186.

BASSETT, M.G. 1984. Life strategies of Silurian brachiopods. Special Papers in Palaeontology, 32, pp. 237-263.

Bergstrom, J. 1968. Some Ordovician and Silurian brachiopod assemblages. Lethaia, 1, pp. 230-237.

BotTJER, D.J. and Ausich, W.I. 1986. Phanerozoic development of tiering in soft substrata suspension-feeding communities. Paleobiology, 12, pp. 400-420.

Bretsky, P.W., JR. 1969. Upper Ordovician ecology of the central Appalachians. Peabody Museum of Natural History, Bulletin, 34, pp. 1-150.

Bulman, O.M.B. 1964. Lower Palaeozoic plankton. Quarterly Journal of the Geological Society of London, 120, pp. 455476.

Cocks, L.R.M. and RonG, JA-YU. 1988. A review of the late Ordovician Foliomena brachiopod fauna with new data from China, Wales and Poland. Palaeontology, 31, pp. 53-67.

Conway Morris, S. 1985. The middle Cambrian metazoan Wiwaxia corrugata (Matthew) from the Burgess Shale and Ogygopsis Shale, British Columbia, Canada. Philosophical Transactions of the Royal Society, London, B307, pp. 507-582.

Conway Morris, S., Pickerill, R.K., and Harland, T.L. 1982. A possible annelid from the Trenton Limestone (Ordovician) of Quebec, with a review of fossil oligochaetes and other annulate worms. Canadian Journal of Earth Sciences, 199, pp. 2150-2157.

CURRY, G.B. 1983. The ecology of the Recent deep-water rhynchonellid brachiopod Cryptopora from the Rockall Trough. Palaeogeography, Palaeoclimatology, Palaeoecology, 44, pp. 93-102.

ETHERIDGe, R. 1876. On an adherent form of Productus and small Spiriferina from the Lower Carboniferous Limestone Group of the East of Scotland. Quarterly Journal of the Geological Society of London, 3, pp. 454-465.

Grant, R.E. 1963. A Permian productoid brachiopod: life history. Science, 152 , pp. 660-662.

Harland, T.L. and Pickerill, R.K. 1982. A review of Middle Ordovician sedimentation in the St. Lawrence Lowland, eastern Canada. Geological Journal, 17, pp. 135-156.

---- 1987. Epizoic Schizocrania sp. from the Ordovician Trenton Group of Quebec, with comments on mode of life of conulariids. Journal of Palaeontology, 61, pp. 844-849.

HARPER, D.A.T. 1979. The environmental significance of some faunal changes in the Upper Ardmillan succession (Upper Ordovician), Girvan, Scotland. Special Publication of the Geological Society of London, 8, pp. 439-445.

Harper, D.A.T., OWen, A.W., and Williams, S.H. 1985. The Middle Ordovician of the Oslo Region, Norway, 34. The type Nakholmen Formation (upper Caradoc), Oslo, and its faunal significance. Norsk Geologisk Tidsskrift, 64, pp. 293-312.

Harper, D.A.T., Doyle, E.N., and Donovan, S.K. 1995. Palaeoecology 
and palaeobathymetry of Pleistocene brachiopods from the Manchioneal Formation of Jamaica. Proceedings of the Geologists' Association, 106, pp. 219-227.

Harper, D.A.T., Donovan, S.K., and Veltkamp, C.J. 1996. The micromorphic articulate brachiopod Gwynia from the Western Approaches. U.K. Journal of Palaeontology, 70, pp. 331333.

Havltcek, V. 1967. Brachiopods of the suborder Strophomenida in Czechoslovakia. Rozpravy Ústavu Geologického, 33, 235 p.

Holland, C.H. 1971. Some conspicuous participants in Palaeozoic symbiosis. Scientific Proceedings of the Royal Dublin Society, A4, pp. 15-26.

JAANUSSON, V. 1984. Ordovician benthic faunal associations. In Aspects of the Ordovician System. Edited by D.L. Bruton. Palaeontological Contributions from the University of Oslo, 295, Univesitetsforlaget, Oslo, pp. 127-139.

Lavole, D. 1995. A Late Ordovician high-energy temperate-water carbonate ramp, southern Quebec, Canada: implications for Late Ordovician oceanography. Sedimentology, 42, pp. 95-116.

Muir-Wood, H.M. 1959. Report on the Brachiopoda of the John Murray Expedition. Bulletin of the British Museum of Natural History, John Murray Expedition 1933-1934. Scientific Report, 10, pp. 283-317.

Pickerill, R.K. and Forbes, W.H. 1978. A trace fossil preserving its producer (Trentonia shegiriana) from the Trenton limestone of the Quebec City area. Canadian Journal of Earth Sciences, 15, pp. 659-664.

----1 1979. Ichnology of the Trenton Group in the Quebec City area. Canadian Journal of Earth Sciences, 16, pp. 2022-2039.

RAYMOND, P.E. 1920. The appendages, anatomy, and relationships of trilobites. Memoirs of the Connecticut Academy of Arts and Sciences, 7, pp. 1-169.
Richardson, J.R. 1981a. Brachiopods and pedicles. Paleobiology, 7, pp. 87-95.

.... 1981b. Brachiopods in mud: resolution of a dilemma. Science, 211, pp. 1161-1163.

RONG, JA-YU, HARPER, D.A.T., ZhAN, REN-BIN, and Ll, RONGYU. 1994. Kassinella-Christiania Associations of the early Ashgill Foliomena brachiopod fauna of South China. Lethaia, 27, pp. 19-28.

SANDY, M.R. 1996. Oldest record of peduncular attachment of brachiopods to crinoid stems, upper Ordovician, Ohio, U.S.A. (Brachiopoda; Atrypida: Echinodermata; Crinoidea). Journal of Paleontology, 70, pp. 532-534.

Schumann, D. 1969. 'Byssus' - artigen Stielmuskel - Konvergenzen bei artikulaten Brachiopoden. Neues Jahrbuch fur Geologie und Paläontologie Abhandlungen, 133, pp. 199-210.

Sheehan, P.M. 1976. Ordovician and Silurian brachiopods from graptolitic shales and related deep-water argillaceous rocks. Lethaia, 10, pp. 201-203.

Størmer, L. 1939. Studies on trilobite morphology. Part I. The thoracic appendages and their phylogenetic significance. Norsk Geologisk Tidsskrift, 19, pp. 143-273.

-..- 1951. Studies on trilobite morphology. Part III. The ventral cephalic structures with remarks on the zoological position of the trilobites. Norsk Geologisk Tiddskrift, 29, pp. 108158.

Unklesbay, A.G. and Niewoehner, W.B. 1959. Attachment loops on infant brachiopods from the Louisiana Limestone in Missouri. Journal of Palaeontology, 33, pp. 547-549.

Wignall, P.B. and Simms, M.J. 1990. Pseudoplankton. Palaeontology, 33, pp. 359-378.

Wright, A.D. 1968. The brachiopod Dicoelosia biloba (Linnaeus) and related species. Arkiv for Zoologi, 20, pp. 261-319.

Editorial Responsibility : G.L. Williams 